\title{
The Adventures of Religious Freedom: Do Judges Understand Religion?
}

Dr Russell Sandberg,

Lecturer in Law,

Cardiff University ${ }^{1}$

At the dawn of the twenty-first century, something rather unexpected happened: religion became significant again. Since the time of the Enlightenment, great thinkers had been quick to predict that religion would vanish in modern rational society and throughout the twentieth century this broadly became the case. However, the events of the late twentieth and twentyfirst centuries have questioned these long held expectations about the decline of religion. One of the most noteworthy, but often overlooked, changes relates to law. Religious freedom is now recognised as a human right and discrimination on grounds of religion or belief has become explicitly prohibited. These new laws have led to a significant increase in litigation and discussion of 'religious rights' (a process which may be referred to as the 'juridification of religion'). And long-standing assumptions and values have become questioned. The relationship between law and religion has become increasingly important and increasing controversial. This paper looks at several recent high profile effects in order to determine the effect of this 'juridification of religion'. Cases concerning prayers said at Council meetings, refusals to give urine samples and protests outside St Pauls Cathedral will be amongst those examined to determine whether judges truly understand religion and the extent to which the new legal framework is working.

\section{A Scandal in Bideford}

In February 2012, the High Court decision in National Secular Society v Bideford Town Council $^{2}$ caught the attention of the media. The case concerned a former councillor who challenged the Town Council's practice of having prayers at the beginning of their council meetings. The tone of the media coverage suggested that this was another one of those cases where traditional British values were being challenged by new and dangerous laws. However, reference to the Law Reports points to a slightly different conclusion.

\footnotetext{
${ }^{1}$ This paper was originally presented at a staff seminar in Keele University on 21 March 2012.

2 [2012] EWHC 175 (Admin).
} 
It is correct that the former councillor, $\mathrm{Mr}$ Bone, argued that the practice of saying prayers breached his right not to be (indirectly) discriminated against on grounds of non-belief under the Equality Act $2010^{3}$ and his right to freedom of religion under Article 9 of the European Convention on Human Rights (ECHR). ${ }^{4}$ However, both of these arguments were unsuccessful. ${ }^{5}$ The challenge against the practice of saying prayers succeeded because of a technicality found in local government law, which has subsequently been removed. ${ }^{6}$

The way in which the case was represented in the media points to one of the main ironies concerning the interaction between law and religion in twenty-first century Britain. Ironically, although the last decade has seen the enactment of many laws protecting religious freedom, there is a feeling amongst many religious believers that legal protection has decreased rather than increased. Some Christians have even gone as far as to talk in terms of persecution. For example, the former Archbishop of Canterbury, Lord Carey of Clifton, provided a witness statement to the Court of Appeal judgment of McFarlane v Relate in

\footnotetext{
${ }^{3}$ See para 57: 'If the Council is entitled to have public prayers at its formal meetings, contrary to my first conclusion, they are also an optional part of the lawful conduct of Council meetings and business of the Council to which Mr Bone was elected, and by the rules of which he has to abide. It is he who is seeking that a lawful but optional practice, chosen here by the majority of Councillors, which is the way in which such decisions are lawfully made, should be stopped to accommodate his particular lack of beliefs. His beliefs or lack of them have in fact been accommodated, and he would be seeking something more than a dispensation or special rule to accommodate him. He is seeking that others abandon a practice, lawfully chosen, which it is lawful for them to choose, so that he does not have to make any accommodation for them, but they do for him. I do not see that the feelings of discomfort or exclusion which he has, and which he says are shared by a number of other actual or possible Councillors in the minority on this issue, should be regarded as a discriminatory disadvantage when its elimination would prevent the degree of comfort or composure which the majority seek being achieved, merely substituting one set of uncomfortable feelings for another.'

4 See para 74: 'The starting point, again, is that, contrary to my first conclusion, there is no statutory bar on the practice of saying prayers as they are currently said. Mr Bone is free to stay or leave during prayers. It is in accordance with the law. It is not discriminatory, or to the extent that it is, it is justified. I cannot see that his freedom of religion, thought or conscience is infringed by the degree of embarrassment he feels, which is no more than is inherent in the exercise by the others of their freedom to manifest their religious beliefs, and his freedom to stay without participating or to leave. It is their freedom which would be infringed were he right; that limitation is not prescribed by law - on the hypothesis that there is no restriction in the LGA 1972. S13 of the Human Rights Act is relevant here' But see also para 75.

${ }^{5}$ See para 80: 'The saying of prayers as part of the formal meeting of a Council is not lawful under s111 of the Local Government Act 1972, and there is no statutory power permitting the practice to continue. If it were lawful, the manner in which the practice is carried out in the circumstances of Bideford does not infringe either Mr Bone's human rights nor does it unlawfully discriminate indirectly against him on the grounds of his lack of religious belief'.

${ }^{6}$ Section 111(1) of the Local Government Act 1972 stated that a 'local authority shall have the power to do anything which is, calculated to facilitate, or is conductive or incidental to, the discharge of their functions'. Ouseley $\mathbf{J}$ interpreted this as meaning that the saying of prayers as part of the meeting was ultra vires. Section 1(1) of the Localism Act 2011 now provides that 'A local authority has power to do anything that individuals generally may do'. This is now in force in England: Localism Act 2011 (Commencement No. 3) Order No. 411 7 [2010] EWCA Civ 880. The case concerned a Christian counsellor who was dismissed because he refused to counsel same-sex couples on sexual matters. See further R Sandberg, 'Laws and Religion: Unravelling McFarlane v Relate Avon Ltd’ (2010) 12 Ecclesiastical Law Journal 361.
} 
which he argued for 'a specially constituted Court of Appeal of five Lords Justices who have a proven sensibility to religious issues, ${ }^{8}$, expressing concern that:

'recent decisions of the Courts have illuminated insensitivity to the interests and needs of the Christian community and represent disturbing Judgments. The effect of these decisions is to undermine the religious liberties that have existed in the United Kingdom for centuries'.

Lord Carey is not alone in raising these concerns. Baroness Warsi has recently warned that Britain is under threat from a rising tide of 'militant secularisation' whereby religion is being 'sidelined, marginalised and downgraded in the public sphere'. ${ }^{10}$ And a recent inquiry by Christians in Parliament (an official All-Party Parliamentary Group) concluded that:

'Christians in the UK face problems in living out their faith and these problems have been mostly caused and exacerbated by social, cultural and legal changes over the past decade., 11

However, many commentators often express their concerns in slightly more nuanced ways than the former Archbishop of Canterbury. For example, the Bishop of Bradford, Nick Baines, has commented that:

'I don't believe Christians are being persecuted. Having said that, I do think there is still a degree of religious illiteracy which is prejudiced against Christians in some circumstances'. 12

Although these concerns are ironic given the increase in laws concerning religion, they are by no means unsurprising. The last decade has witnessed a clear trend towards what I have referred to as 'the juridification of religion'. ${ }^{13}$ The opening years of the twenty-first century

\footnotetext{
${ }^{8}$ [2010] EWCA Civ 880, at para. 17.

${ }^{9}$ See para. 6 of the Witness Statement.

${ }^{10}$ See http://www.bbc.co.uk/news/uk-17021831> and <http://www.telegraph.co.uk/news/religion/9080441/Westand-side-by-side-with-the-Pope-in-fighting-for-faith.html>

${ }^{11}$ See the 'Clearing the Ground Inquiry' Published by Christians in Parliament $<$ http://www.eauk.org/clearingtheground/>.

12 See <http://www.guardian.co.uk/ world/2011/Jul/10/christian-mp-inquiry-religious-discrimination>

${ }^{13}$ See R Sandberg, Law and Religion (Cambridge University Press, 2011) chapter 10.
} 
has seen the enactment of a number of very controversial laws concerning religion, such as the Human Rights Act $1998^{14}$, developments in discrimination law ${ }^{15}$ and religious offences such as the Racial and Religious Hatred Act 2006. ${ }^{16}$ These have promoted the language of 'religious rights' but have led to a number of high profile cases where claims made by religious believers have been unsuccessful.

In many of these cases, the unsuccessful outcome has been unsurprising since many claims have been vexatious (in part because the intentions of the new laws were misunderstood or unclear). However, it is the reasoning employed in such cases rather than the decisions themselves that have prompted much academic concern. ${ }^{17}$ Indeed, many of the high profile religious rights cases of recent years are currently on the long road to the European Court of Human Rights in Strasbourg. The concern is that English courts seem to be interpreting religious rights in a very narrow, conservative and Western manner which risks leaving Article 9 of the European Convention of Human Rights 1950 (ECHR) moribund and religion less protected than the other equality strands found in the Equality Act 2010. And this tendency can be terraced back to what can now be seen as a watershed decision in the protection of religious freedom in England and Wales: the 2006 decision of the House of Lords in $R$ (on the application of Begum) $v$ Headteacher and Governors of Denbigh High School ${ }^{18}$.

\section{The Begum Precedent}

The case of Begum attracted a great deal of media and academic comment since it concerned the wearing of Islamic dress (a jilbab) at school. However, the reasoning of the House of Lords has proved to be of more importance than its decision. The case concerned the interpretation of Article 9 ECHR, which reads:

1. Everyone has the right to freedom of thought, conscience and religion; this right includes freedom to change his religion or belief, and freedom, either alone or in

\footnotetext{
${ }^{14}$ See ibid chapter 5 .

15 Ibid chapter 6.

${ }^{16}$ Ibid chapter 7.

${ }^{17}$ See, e.g., M Hill and R Sandberg 'Is Nothing Sacred? Clashing Symbols in a Secular World' (2007) Public Law 488-506; I Leigh, 'Recent Developments in Religious Liberty' (2009) 11 Ecclesiastical Law Journal 6572.; and N Gibson, 'Faith in the Courts: Religious Dress and Human Rights' (2007) Cambridge Law Journal 696.

${ }^{18}$ [2006] UKHL 15.
} 
community with others and in public or private, to manifest his religion or belief, in worship, teaching, practice and observance.

2. Freedom to manifest one's religion or beliefs shall be subject only to such limitations as are prescribed by law and are necessary in a democratic society in the interests of public safety, for the protection of public order, health or morals, or the protection of the rights and freedoms of others.

There are at least two rights found in Article 9(1): the absolute right to freedom of thought, conscience and religion and the qualified right to manifest religion or belief. This means that people can believe whatever you want but once they act on that belief then such manifestations can be limited in the circumstances prescribed in Article 9(2). If the court holds that there is interference under Article 9(1), it then moves on to discuss whether that interference was justified under Article 9(2).

In Begum the House of Lords were unanimous in their disposal of the appeal. However, their reasoning differed. Lord Nicholls and Lady Hale held that there had been an interference with Article 9(1) but that it had been justified under Article 9(2). In contrast, Lords Bingham, Hoffmann and Scott held that there had been no interference with Article 9(1). The school's refusal to allow a pupil to wear religious dress did not interfere with that pupil's religious freedom. It is the reasoning of Lords Bingham, Hoffmann and Scott that has proved to be influential.

Paragraphs 23 and 24 of Lord Bingham's speech have proved particularly important. Lord Bingham began paragraph 23 by suggesting:

'The Strasbourg institutions have not been at all ready to find an interference with the right to manifest religious belief in practice or observance where a person has voluntarily accepted an employment or role which does not accommodate that practice or observance and there are other means open to the person to practise or observe his or her religion without undue hardship or inconvenience'.

After citing a series of Strasbourg cases in support of this proposition, his Lordship concluded in paragraph 24 as follows: 
'the authorities do in my opinion support the proposition with which I prefaced para 23 of this opinion. Even if it be accepted that the Strasbourg institutions have erred on the side of strictness in rejecting complaints of interference, there remains a coherent and remarkably consistent body of authority which our domestic courts must take into account and which shows that interference is not easily established.'

That final sentence has been quoted in several judgments since, often to support a finding that there has been no interference with the claimant's Article 9 rights. It is that final remark that I find problematic. On my reading of Strasbourg jurisprudence to state that 'interference is not easily established' is to over-state the law. This sentence has far too often been interpreted to mean that interference will not be readily established and has warranted the placing of high thresholds that need to be met before Article 9(1) can be said to have been engaged. Moreover, there is doubt as to what the "coherent and remarkably consistent body of authority' Lord Bingham refers to actually says.

This requires us to turn our attention back to Lord Bingham's proposition found at the start of paragraph 23:

'The Strasbourg institutions have not been at all ready to find an interference with the right to manifest religious belief in practice or observance where a person has voluntarily accepted an employment or role which does not accommodate that practice or observance and there are other means open to the person to practise or observe his or her religion without undue hardship or inconvenience'.

First of all, it is important to note that Lord Bingham was perfectly correct to say that there have been occasions where Strasbourg institutions had held that there had been no interference with Article 9(1). A number of 'filtering devices' have been suggested and used for this purpose: ${ }^{19}$ most notably the assertion in Arrowsmith $v$ United Kingdom, ${ }^{20}$ that the term practice 'does not cover each act which is motivated or influenced by a religion or a belief' and that Article 9 was not interfered with where although the act was 'motivated or influenced' by the claimant's belief, it did not 'actually express the belief concerned'.

\footnotetext{
${ }^{19}$ See R Sandberg, Law and Religion (Cambridge University Press, 2011) chapter 5.

${ }^{20}$ (1981) 3 EHRR 218.
} 
It is also worth noting, however, that the Strasbourg case law on Article 9 is still very much in its infancy and that the more recent decisions by the Court tend to focus less on the question of interference under Article 9(1), preferring instead to focus on the question of interference under Article 9(2).

Moreover, there is some doubt as to the parameters of the particular rule Lord Bingham is referring to. It is important to make two different interpretations of the rule: one emphasising the first element of the rule; the second emphasising the second element. Lord Bingham's rule is that there will be no interference "where a person has voluntarily accepted an employment or role which does not accommodate that practice or observance and there are other means open to the person to practise or observe his or her religion without undue hardship or inconvenience'. ${ }^{21}$

The first interpretation places emphasis upon the first part of the rule ('where a person has voluntarily accepted an employment or role which does not accommodate that practice or observance'). On my reading, this is an elucidation of what I have referred to as the 'specific situation rule'. I have defined this as follows:

'[The specific situation rule] recognises that a person's Article 9 rights may be influenced by the particular situation of the individual claiming that freedom. This principle is not of universal application: it only applies where someone has voluntarily submitted themselves to a system of norms, usually by means of a contract. This voluntary submission creates a "specific situation" which limits the claimant's right to manifest'. 22

The rule often boils down to freedom of contract. If a person has voluntarily submitted themselves to a system of norms they cannot subsequently claim a breach of their Article 9 rights. If I sign a contract to become a school teacher, I cannot then bring an Article 9 claim on the basis that I am not permitted to leave the school to worship on a Friday.

\footnotetext{
${ }^{21}$ Emphasis added.

${ }^{22}$ R Sandberg, Law and Religion (Cambridge University Press, 2011) 84-85.
} 
The Strasbourg case law provides examples of how this rule has been applied. For example, it has been applied in relation to a detained person, ${ }^{23}$ a person who voluntarily submits to military service, ${ }^{24}$ a person who voluntarily enters into a contract of employment ${ }^{25}$ and those who voluntarily enrol at a university. ${ }^{26}$

The cases cited by Lord Bingham in Begum all relate to similar 'specific situations'. Indeed, at paragraph 22 of his speech Lord Bingham cites two Strasbourg decisions which seem in line with my understanding of the specific situation rule. His Lordship quoted from Kalaç $v$ Turkey $^{27}$ in which it was noted that:

'Article 9 does not protect every act motivated or inspired by a religion or belief.

Moreover, in exercising his freedom to manifest his religion, an individual may need to take his specific situation into account'.

And also noted that the Commission ruled to similar effect in Ahmad v United Kingdom ${ }^{28}$

'the freedom of religion, as guaranteed by Article 9, is not absolute, but subject to the limitations set out in Article 9(2). Moreover, it may, as regards the modality of a particular religious manifestation, be influenced by the situation of the person claiming that freedom.'

Lord Bingham also quoted from the speech of Lord Nicholls in $R v$ Secretary of State for Education and Employment and others ex parte Williamson ${ }^{29}$, in which it was stated that:

'What constitutes interference depends on all the circumstances of the case, including the extent to which in the circumstances an individual can reasonably expect to be at liberty to manifest his beliefs in practice'. ${ }^{30}$

\footnotetext{
${ }^{23} X v$ United Kingdom (1974) 1 D\& R 41 (on the basis that the prisoner had broken his contract with society).

${ }^{24}$ Kalaçv Turkey (1997) 27 EHRR 552.

${ }^{25}$ Stedman v United Kingdom (1997) 5 EHRLR 544; Ahmad v United Kingdom (1981) 4 EHRR 126.

${ }^{26}$ Karaduman v Turkey (1993) 74 DR 93.

27 (1997) 27 EHRR 552, para 27.

${ }^{28}$ (1981) 4 EHRR 126, para 11.

${ }^{29}$ [2005] UKHL 15.

${ }^{30}$ Para 38.
} 
Although this might sound like a broader version of the specific situation rule, Lord Nicholls then went on to cite the extract from Kalac given above and then went on to hold that:

'In the present case there is no comparable special feature affecting the position of the claimant parents. ${ }^{, 31}$

This would seem to emphasize how the rule is not of general application.

However, there is a second possible interpretation of Lord Bingham's rule that draws the rule in broader terms than I have understood the specific situation rule. This interpretation places a greater emphasis upon the second part of the rule:

'The Strasbourg institutions have not been at all ready to find an interference with the right to manifest religious belief in practice or observance where a person has voluntarily accepted an employment or role which does not accommodate that practice or observance and there are other means open to the person to practise or observe his or her religion without undue hardship or inconvenience, ${ }^{32}$

This aspect of the rule suggests that there is no interference with Article 9 where the there are other ways open to the claimant to manifest their religion. This aspect of the rule is emphasized by Malehia Malik in her understanding of what she refers to as the "contracting out doctrine'. ${ }^{33}$ In her feminist judgment on the Begum case she writes that:

'the contracting out doctrine is based on the idea that there is no interference with freedom of religion where the individual is left with a viable and voluntary choice to put themselves in a position where they can manifest their religion, even if this requires some personal sacrifice. ${ }^{34}$

\footnotetext{
${ }^{31}$ Para 39.

${ }^{32}$ Emphasis added.

${ }^{33}$ M Malik, 'Judgment: $R(S B)$ v Denbigh High School' in R Hunter et al (eds) Feminist Judgments: From Theory to Practice (Hart, 2010).

${ }^{34}$ Para 9.
} 
This does not mean that the first limb of the test is redundant. ${ }^{35}$ However, the contracting out doctrine does seem to place more emphasis upon this second aspect of Lord Bingham's rule. Indeed, under Malik's interpretation the word 'and' in Lord Bingham's test seems to become an 'or':

'where an individual either puts themselves into a situation that restricts their religious freedom in some way, or has a choice that would allow them to change their situation in a way that allows them to exercise their religious freedom, it is assumed that there has been no interference'. ${ }^{36}$

This emphasis seems to be followed in Begum itself with considerable stress being placed upon the issue of whether she could have gone to another school. In contrast, less attention is given to the question of whether Begum voluntarily submitted to the system of norms; though as Baroness Hale suggested this is a significant issue based on the facts. ${ }^{37}$

'Most of your lordships take the view that Shabina Begum's right to manifest her religion was not infringed because she had chosen to attend this school knowing full well what the school uniform was. It was she who had changed her mind about what her religion required of her, rather than the school which had changed its policy. I am uneasy about this. The reality is that the choice of secondary school is usually made by parents or guardians rather than by the child herself. The child is on the brink of, but has not yet reached, adolescence. She may have views but they are unlikely to be decisive. More importantly, she has not yet reached the critical stage in her development where this particular choice may matter to her'. ${ }^{38}$

Although the Strasbourg institutions have not been consistent in their articulation and application of this principle, it would seem to be the case that the emphasis upon the second limb of the test in Begum is out of step with the Strasbourg jurisprudence. This is shown by

\footnotetext{
${ }^{35}$ Malik seems to suggest that it is the voluntary acceptance of a situation where the religious practice is not permitted that brings about the choice element: 'In these fact situations individuals have, thorough exercise of choice, put themselves in a situation which limits their ability to manifest their religion': para 9.

${ }^{36}$ Para 6.

${ }^{37}$ Malik makes a similar point: M Malik, 'Judgment: $R(S B) v$ Denbigh High School' in R Hunter et al (eds) Feminist Judgments: From Theory to Practice (Hart, 2010).

38 [2005] UKHL 15 at para 92.
} 
the case of Şahin $v$ Turkey $^{39}$, concerning a university regulation banning a student from wearing a headscarf at enrolment, lectures and examinations. The facts of the case were more in keeping with both the 'specific situation rule' and the 'contracting out doctrine' as discussed above. However, although the Court noted vaguely that 'Article 9 does not protect every act motivated or inspired by a religion or belief and does not in all cases guarantee the right to behave in the public sphere in a way which is dictated by a belief', ${ }^{40}$ the Court proceeded 'on the assumption that the regulations in issue, which placed restrictions of place and manner on the right to wear the Islamic headscarf in universities, constituted an interference with the applicant's right to manifest her religion. ${ }^{41}$ In other words, the approach favoured by Lord Nicholls and Lady Hale in Begum was taken: it was held that there had been an interference with Article 9(1) it had been justified under Article 9(2).

Şahin v Turkey seems typical of the approach usually taken by Strasbourg but there is one notable exception to this trend: in Jewish Liturgical Association Cha'are Shalom Ve Tsedek $v$ France $^{42}$ Strasbourg seemed to go further by imposing an 'impossibility test': the Court commented that an 'alternative means of accommodating religious beliefs had ... to be "impossible" before a claim of interference under article 9 could succeed'. This would give general application to the rule, effectively meaning that only the second part of Lord Bingham's rule stands.

However, both Strasbourg and domestic courts have declined to follow the Jewish Liturgical case. As Lord Nicholls noted in Williamson ${ }^{43}$ :

'In passing, I doubt whether by the use of the word "impossible" in Jewish Liturgical Association Cha'are Shalom Ve Tsedek v France (2000) 9 BHRC 27, 46, para 80, the European Court of Human Rights was intending to enunciate a standard which is less protective. That would be inconsistent with the bedrock principle that human rights Conventions are intended to afford practical and effective protection to human rights. The court's decision in that case was based on the apparent ease with which the

\footnotetext{
${ }^{39}$ (2005) 41 EHRR 8.

${ }^{40}$ Para 66.

${ }^{41}$ Para 71.

42 (2000) 9 BHRC 27.

43 [2005] UKHL 15.
} 
applicant association could obtain supplies of "glatt" kosher meat elsewhere, as noted in paras $81-83$ of its judgment', ${ }^{44}$

Lord Bingham referred to this in Begum ${ }^{45}$ while Lord Hoffmann also seemed to doubt the Jewish Liturgical rule, commenting: "Impossible" may be setting the test rather high but in the present case there is nothing to show that Shabina would have even found it difficult to go to another school' ${ }^{46}$

However, ironically, the way in which the majority of the House saw the fact that she could go to another school was definitive means that English law moved towards this 'impossibility test'. The focus on the second limb of Lord Bingham's test meant that the emphasis was on the possibility of 'contracting-out' rather than the identification of a specific situation rule. This means that the rule now has general effect.

\section{A Uniform Approach ${ }^{47}$}

A series of cases concerning school uniforms followed Begum by holding that there was no interference with Article 9 since the claimant was free to go to another school.

In $R$ (on the application of $X) \vee Y$ School $^{48}$ Silber J grappled with the two elements of Lord Bingham's rule, labelling them as follows:

'The Strasbourg institutions have not been at all ready to find an interference with the right to manifest religious belief in practice or observance [A] where a person has voluntarily accepted an employment or role which does not accommodate that practice or observance and $[\mathrm{B}]$ there are other means open to the person to practise or observe his or her religion without undue hardship or inconvenience'.

Silber J effectively concluded that the 'and' between limbs A and B should be read as if it said 'or'. He held that:

\footnotetext{
${ }^{44}$ At para 38.

${ }^{45}$ [2006] UKHL 15 at para 24.

${ }^{46}$ At para 52.

${ }^{47}$ See further R Sandberg, Law and Religion (Cambridge University Press, 2011) 92-93.

${ }^{48}$ [2006] EWHC (Admin) 298.
} 
'the passage from Lord Bingham's speech, which I quoted in paragraph 26 above does not state that there will not be breach of article 9 rights only in a case in which the requirements of each of the limbs (A) and (B) is satisfied'. 49

Silber J held that he was 'persuaded that the claimant's article 9 rights have not been infringed by the school's decision not to allow her to wear the niqab for four reasons':.

1. Lord Scott in Begum had held that there would be no interference with Article 9 'where the individual has a choice whether or not to avail himself or herself of the services of that institution, and where other public institutions offering similar services, and whose rules do not include the objectionable rule in question, are available'. 51

2. Lord Hoffmann in Begum had said that 'Article 9 does not require that one should be allowed to manifest one's religion at any time and place of one's own choosing' ${ }^{52}$

3. Citing the Jewish Liturgical case, it was observed that 'Strasbourg case law shows that there is no interference with an article 9 right where there is an alternative place at which the services in question can be provided without the objectionable rule in question'. 53

4. Lord Bingham in Begum had suggested that the 'approach in Strasbourg courts to complaints that an applicant has been unable to manifest his or her religion or belief has been to impose a high threshold before interference can be established' ${ }^{54}$

From this reasoning it is clear why Silber $\mathbf{J}$ saw the Begum decision as 'an insuperable barrier' to the claim. ${ }^{55}$ However, these reasons are simply elaborations in Begum of what Silber J designated as part B. They simply explain that aspect of the Lord Bingham's rule,

\footnotetext{
${ }^{49}$ At para 29.

${ }^{50}$ Para 30.

${ }^{51}$ Para 31, citing Begum at para 87.

${ }_{53}^{52}$ Para 32, citing Begum at para 50.

${ }^{53}$ Para 33.

${ }_{55}^{54}$ Para 38, citing Begum at para 24.

55 Para 100.
} 
failing to observe that part A also needs to be met. Silber J concluded his analysis by observing:

'I have not been shown or found any decision of the European Court of Human Rights or of any English court in which it was held that there was an infringement of person's article 9 rights when he or she could without excessive difficulty manifest or practice their religion as they wished in another place or in another way. The approach in Strasbourg courts to complaints that an applicant has been unable to manifest his or her religion or belief has been to impose a high threshold before interference can be established'. ${ }^{56}$

The context of this discussion, as shown by the final sentence of the quote, seems to suggest that Silber J is regarding the terms 'infringement' and 'interference' to be synonymous. If this is true, his beginning statement is simply erroneous. Sahin and Williamson are just two examples of cases where it was held that there was an interference with Article 9 where the claimant could have manifested their religion elsewhere. It is true that both of those Article 9 claims failed but they did so on grounds of justification not interference. It was accepted that the manifestations came within the scope of Article 9(1) but was then held that the interference was justified under Article 9(2).

Like $X v Y$, the decision in $R$ (on the Application of Playfoot (A Child) v Millais School Governing Body ${ }^{57}$ followed Begum in placing more emphasis on the fact that the claimant could manifest her religion easily at another school. This brings the law in line with the questioned impossibility rule found in the Jewish Liturgical case.

The decision in Playfoot concerned the wearing of a 'purity ring' at school as a sign of sexual restraint and the claimant's decision to remain a virgin until marriage because she was a Christian. Supperstone QC, sitting as a High Court judge, held that the wearing of a purity ring was not a manifestation of her religion for the purposes of Article 9 since:

\footnotetext{
${ }^{56}$ Para 38.

${ }^{57}$ [2007] EWHC Admin 1698.
} 
'In my judgment the act of wearing a ring is not "intimately linked" to the belief in chastity before marriage. ... The Claimant was under no obligation, by reason of her belief, to wear the ring; nor does she suggest that she was so obliged' ${ }^{58}$

In reaching this conclusion, Supperstone QC relied upon paragraph 32 of Lord Nicholls' speech in Williamson in which his Lordship observed:

'in deciding whether the claimants' conduct constitutes manifesting a belief in practice for the purposes of article 9 one must first identify the nature and scope of the belief. If, as here, the belief takes the form of a perceived obligation to act in a specific way, then, in principle, doing that act pursuant to that belief is itself a manifestation of that belief in practice. In such cases the act is 'intimately linked' to the belief, in the Strasbourg phraseology'.

Lord Nicholls is saying that if an action is obligatory under the religion in question then that means that it is likely that doing that action will be seen as a manifestation. However, this does not mean that the reverse is true. If an action is not obligatory, it does not follow that it cannot be a manifestation. Supperstone QC appears to have overlooked paragraph 33 Nicholls' speech in Williamson which makes this very point:

'This is not to say that a perceived obligation is a prerequisite to manifestation of a belief in practice. It is not: see, for instance, Syndicat Northcrest v Amselem 241 DLR (4th) 1, esp at 25-26, paras 46-50. I am concerned only to identify what, in principle, is sufficient to constitute manifestation in a case where the belief is one of perceived obligation'.

Supperstone QC then went on to consider the rule given by Lord Bingham in Begum. First, he noted the evidence of 'voluntary acceptance', noting that the uniform was publicised to both parents and pupils and that 'the School was the Claimant's first preference'. ${ }^{59}$ No concession was made to the fact that the school was probably the parent's rather than the child's choice or that the child's religious observance may have changed overtime as she matured. Second, he noted 'other means by which the Claimant [could] express her belief' such as by attaching

\footnotetext{
${ }^{58}$ Para 23.

${ }^{59}$ Para 29.
} 
the ring to her bag, wearing a badge or sticker instead, contributing to PSHE classes on the topic or by transferring to another school. ${ }^{60}$ It is doubtful whether such 'alternatives' would have been considered if the claimant had sought to wear an Islamic veil or a Sikh turban. Nevertheless, Supperstone QC concluded that this meant that there had been no interference under Article 9:

'the Claimant's Article 9 rights have not been interfered with both because she voluntarily accepted the uniform policy of the School which does not accommodate the wearing of the ring and there are other means open to her to practice her belief without undue hardship or inconvenience'. ${ }^{61}$

\section{The Rise and Fall of Religious Discrimination Law}

For a time, the extension of discrimination law to specifically prohibit discrimination on grounds of religion or belief filled the gap created by Begum. ${ }^{62}$ The only successful case concerning the wearing of religious dress at school was successful because it was argued solely on grounds of discrimination law: religious freedom was not part of the legal arguments. $^{63}$

Laws on indirect discrimination were used to circumvent the rule put forward by Lord Bingham in Begum which meant that Article 9 had little application in the employment sphere (since employees could simply resign). In particular, a number of indirect discrimination claims about working hours and holy days were successful. ${ }^{64}$ If the employer changed your working hours in ways which prevented you from manifesting your religion, then that constituted discrimination unless it could be shown to be justified.

However, this was not to last. ${ }^{65}$ A number of high profile claims brought under religious discrimination laws were dismissed on the basis that there was no 'disadvantage', as opposed

\footnotetext{
${ }^{60}$ Para 30.

${ }^{61}$ Para 32.

${ }^{62}$ Employment Equality (Religion or Belief) Regulations 2003; Equality Act 2006. See now the Equality Act 2010 .

${ }^{63} R$ (on the application of Watkins-Singh) v The Governing Body of Aberdare Girls' High School [2008] EWHC (Admin) 1865, discussed by R Sandberg, Law and Religion (Cambridge University Press 2011) 96-98.

${ }^{64}$ See, eg. Khan v G \& S Spencer Group ET, Case Number 1803250/2004 (12 January 2005); Williams-Drabble v Pathway Care Solutions ET, Case Number: 2601718/2004 (2 December 2004); Fugler v MacMillan - London Hairstudios Limited ET, Case Number: 2205090/2004 (21-23 June 2005).

${ }^{65}$ See R Sandberg, Law and Religion (Cambridge University Press 2011) chapter 6.
} 
to accepting that there had been a disadvantage but that disadvantage had been justified. The most publicised, and concerning, such case was that of Eweida $v$ British Airways ${ }^{66}$, which reached the Court of Appeal.

In Eweida the Court of Appeal held that BA's then uniform policy which prohibited the wearing of visible religious symbols unless their wearing was mandatory did not constitute indirect discrimination. The Court held that the uniform policy did not put Christians at a particular disadvantage because there was no evidence that practising Christians considered the visible display of the cross to be a requirement of the Christian faith.

In other words, there is only religious discrimination where a believer is stopped from doing something which is obligatory in the faith in question and where their co-religionists agree that it is obligatory. This means that fringe beliefs held by a few individuals (including beliefs held by a minority of believers within a larger religious group) will be denied protection.

Eweida was followed by the Employment Tribunal decision in Chaplin v Royal Devon \& Exeter NHS Foundation Trust ${ }^{67}$, which concerned a nurse who wished to wear a crucifix around her neck. Despite evidence that another nurse had been asked to remove her cross and chain, ${ }^{68}$ the Employment Tribunal held that this other nurse had not been put at a particular disadvantage since her religious views were not so strong as to lead her to refuse to comply with the policy. It was held that in order for there to be a 'particular disadvantage', the disadvantage needed to be 'noteworthy, peculiar or singular'. ${ }^{69}$

In Begum, $X v Y$, Playfoot, Eweida and Chaplin the judges have restricted the scope of the new law failing to protect claims which fall outside a conservative view of religion. Those who can manifest their religion elsewhere have been excluded and so have those whose beliefs are not, in the eyes of the court, required or obligatory to the religion in question or those whose beliefs are not shared by the mainstream of the religion.

\footnotetext{
66 [2010] EWCA Civ 80.

${ }^{67}$ [2010] ET Case Number: 17288862009 (6 April 2010).

${ }^{68}$ See para 15.

${ }^{69}$ Para 27.
} 
All of these claims were dismissed on grounds of interference / disadvantage. In all of the cases, the question of whether the interference was justified was obiter.

This reliance upon the question of interference is unnecessary because more often than not such claims could have been adequately dealt with by focusing upon the question of justification. ${ }^{70}$ Increasingly high barriers seem to be placed in front of those who wish to enforce what they believe to be their religious rights. And the tendency to focus upon semantic questions of interference might not allow the court to examine the merits of the case. Cases concerning religious rights require nuanced, fact-specific judgments, which are best reached by focussing upon the question of justification. The current case law indicates that the judiciary are uncomfortable dealing with religious rights, clinging to questions of interference to deal swiftly with claims. This is not to say that the 'religion or belief' argument always needs to win. However, the 'religion or belief' argument needs to be considered seriously and treated as being as important as other rights.

However, dismissing claims on the basis of interference is convenient. It allows judges to dismiss claims by simply applying a legal test. It is not their fault, they could claim, that the case is dismissed. They are simply following the law. And discussing the question of justification as a hypothetical obiter question means that difficult questions can be avoided.

\section{Towards a Hierarchy of Rights}

The effect of Begum was that Article 9 became moribund and although new provisions outlawing religious discrimination provided some remedy in lieu of Article 9, the case of Eweida shows that a restrictive approach has also been taken there. This has meant that religious rights are easily 'trumped' by other rights. ${ }^{71}$ This is especially true of a number of high profile cases where there has been a clash between discrimination on grounds of sexual orientation and discrimination on grounds of religion. Rather than attempting to balance these rights, courts and tribunals have readily accepted that the need to eliminate discrimination on grounds of sexual orientation is an answer to a charge of religious discrimination.

\footnotetext{
${ }^{70}$ R Sandberg, Law and Religion (Cambridge University Press 2011) 199.

${ }^{71}$ See, further, R Sandberg 'The Right to Discriminate' (2011) 13 Ecclesiastical Law Journal 157.
} 
Most notably, the Court of Appeal decision in Ladele v London Borough of Islington ${ }^{72}$ concerned a registrar who refused on grounds of conscience to perform civil partnership ceremonies. The claim that this constituted indirect discrimination on grounds of religion was dismissed on the basis that any disadvantage was justified. ${ }^{73}$ The Court of Appeal held that the employer's policy of promoting equality on grounds of sexual orientation constituted a legitimate aim. For Dyson LJ,

'[The aim of the Council's Dignity for All policy] was of general, indeed overarching, policy significance [having] fundamental human rights, equality and diversity implications, whereas the effect on Ladele of implementing the policy did not impinge on her religious beliefs: she remained free to hold those beliefs, and free to worship as she wished'. ${ }^{74}$

Further, Ladele was employed in a public job and was being 'required to perform a purely secular task, which was being treated as part of her job' ${ }^{75}$

Aspects of this reasoning are questionable. ${ }^{76}$ The argument seems one-sided. Preventing discrimination on grounds of sexual orientation is described as being of 'overarching, policy significance' whilst freedom of religion is defined very narrowly. Surely the equality policy protects discrimination on grounds of religion as well as on grounds of sexual orientation. Taken literally, the Court of Appeal in Ladele seemed to suggest that freedom of religion only included the right to hold beliefs and worship. This is not the case as the text of Article 9 makes clear. It appears that the laudable aim of preventing discrimination on grounds of sexual orientation was used to annihilate the claim of religious discrimination. Moreover, there seems to be an implicit understanding here that the workplace will be secular and that religion can be left at the door, like an overcoat. Would judges say similar things about other equality strands?

\footnotetext{
${ }^{72}$ Ladele v London Borough of Islington [2009] EWCA (Civ) 1357.

${ }^{73}$ The Court of Appeal also held that claims of direct discrimination on grounds of religion failed because the employer did not treat the employee unfavourably on grounds of religion. Although Ladele's actions were on grounds of religion, their employer's actions were not. She was treated as she was because of her refusal to perform civil partnerships not because of her religious beliefs.

${ }_{74}^{74}$ At para 51. Dyson LJ held that this conclusion was reinforced by Article 9 of the ECHR: see paras 54-61.

${ }^{75}$ Para 52.

${ }^{76}$ See further R Sandberg, 'The Implications of the Court of Appeal Decision in Ladele', paper presented to the Interfaith Legal Advisers Network (Lambeth Palace, $1^{\text {st }}$ March 2010), available as part of the Working Paper Series coordinated by the Centre for Law for Law and Religion at Cardiff University. See:

$<$ http://www.law.cf.ac.uk/clr/research/WorkingPapers.html>
} 
The effect of Ladele can be shown, for example, ${ }^{77}$ in the High Court decision in $R$ (Eunice Johns and Owen Johns) v Derby City Council ${ }^{78}$. The case concerned two would-be foster carers who expressed their beliefs concerning homosexuality whilst being interviewed by the council. The claimants formed the view that the defendant was discriminating them on religious grounds in that the defendant would not seem to be prepared to approve as foster carers any Christians who held similar views as to homosexuality. Accordingly, although the Council's Fostering Panel simply deferred a decision on whether Mr and Mrs John would be suitable foster parents, the claimants launched religious discrimination proceedings.

Munby LJ began by stressing what he regarded as 'the obvious point that we live in this country in a democratic and pluralistic society, in a secular state not a theocracy' ${ }^{79}$ Most of this is not contentious but it is unclear what Munby LJ means by 'secular' ${ }^{80}$ In relation to indirect discrimination, ${ }^{81}$ Eweida was applied to hold that it had not been shown that there had been 'particular disadvantage' or 'group' disadvantage to Christians or the particular denomination of Christianity since: "It is necessary to show "particular disadvantage" or "group" disadvantage to Christians or the particular denomination of Christianity and it is not conceded this has been shown here'. 82

Moreover, Munby LJ held that even if there had been a disadvantage then any indirect discrimination would have been justified by the defendant's need to comply with antidiscrimination legislation prohibiting sexual orientation discrimination and their equal opportunities policies to the same affect:

\footnotetext{
${ }^{77}$ See also the decision in McFarlane v Relate [2010] EWCA Civ 880, discussed by R Sandberg, 'Laws and Religion: Unravelling McFarlane v Relate Avon Ltd' (2010) 12 Ecclesiastical Law Journal 361.

78 [2011] EWHC Admin 375.

79 At para 36.

${ }^{80} \mathrm{He}$ added that: 'Our society is now pluralistic and largely secular. But one aspect of its pluralism is that we also now live in a multi-cultural community of many faiths. One of the paradoxes of our lives is that we live in a society which has at one and the same time become both increasingly secular but also increasingly diverse in religious affiliation' (para 38).

${ }^{81}$ In terms of direct discrimination, the High Court held that had been no direct discrimination on grounds of religion or belief since the defendant's treatment of the claimant had been the result of the claimant's disapproval of same sex relationships rather than because of the claimant's religion or belief. They seemed to interpret the reasoning in Ladele and McFarlane in this respect as a general principle: 'If the defendant's treatment is the result of the claimants' expressed antipathy, objection to, or disapproval of homosexuality and same-sex relationships it is clear, on authorities which bind us, namely the decisions of the Court of Appeal in Ladele and McFarlane, that it would not be because of their religious belief': (Para 99).

${ }^{82}$ Para 101.
} 
'it is clear on the authorities that compliance with anti-discrimination legislation prohibiting sexual orientation discrimination and the defendant's equal opportunities policies to the same effect, together with the need to ensure the non-discriminatory service provisions ... will amount to justification: see [Ladele]. ${ }^{83}$

This seems to suggest that the need not to discriminate on grounds of sexual orientation will always serve as justification to a religious discrimination claim.

Moreover, Munby LJ held that this conclusion was compatible with Article 9. Again, a rather restrictive interpretation was given to the Article, ${ }^{84}$ with Munby LJ observing that:

"Article 9 only provides a "qualified" right to manifest religious belief and that interferences in the sphere of employment and analogous spheres are readily found to be justified, even where the members of a particular religious group will find it difficult in practice to comply, ${ }^{85}$

Although Munby LJ is correct to say that the right to manifest under Article 9 is one of the qualified rights under the Convention, his definition of what 'qualified' seems to say that Article 9 is a very limited right. His insistence that interferences 'are readily found to be justified' is particularly noteworthy given that most of the Article 9 cases have failed on grounds of interference. And the last sentence goes even further than Begum.

In sum, the pattern found in the case law seems to be as follows:

(i) Article 9 claims are failing on grounds of interference (rather than justification) due to the application of the contracting out doctrine (as distinct to the specific situation rule). This is shown in by Begum, as followed by $X v Y$ and Playfoot. Playfoot also suggested that only obligatory religious practices will be protected.

\footnotetext{
${ }^{83}$ Para 101.

${ }^{84}$ The judgment's first discussion of Article 9 is anodyne enough, comprising simply of selected well-meaning quotes from Strasbourg cases to reach the basic conclusion that: ' the Convention forbids the state to determine the validity of religious beliefs and in that respect imposes on the state a duty of what the Strasbourg court has called neutrality and impartiality' (para 48).

${ }^{85}$ At para 102.
} 
(ii) Although discrimination law has led to some successful cases in the context of employment (especially in relation to working hours), a restrictive approach seems to be taken in some cases to the question of disadvantage, especially in respect of ascertaining whether that disadvantage is shared by co-religionists. This is shown in particular by Eweida (which is very much in keeping with the logic of Playfoot).

(iii) A series of cases concerning religious and sexual orientation discrimination claims (Ladele and Johns v Derby City Council) suggest that the need not to discriminate on grounds of sexual orientation will always serve as justification to a religious discrimination claim. This seems to be the strongest evidence to date that there now exist a hierarchy of rights with religious discrimination coming below other equality strands.

However, some recent cases (and a change in stance by the Equality and Human Rights Commission) have indicated that changes may be afoot.

\section{The Return of Article 9}

A significant and so far overlooked case is the High Court decision in $R$ on the Application of Bashir v The Independent Adjudicator and HMP Ryehull and the Secretary of State for Justice. ${ }^{86}$ The case concerned a prisoner, was charged with failing to obey a lawful order contrary to Rule 51(22) of the Prison Rules 1999 when he failed to provide an adequate urine sample as part of the prison's mandatory drug testing policy. Although the claimant was a devout Muslim who was fasting as part of his religious preparation prior to a Court of Appeal appearance, the Independent Adjudicator had found the claimant guilty of failing to obey a lawful order. The Prison Service Order PSO 3601 on 'Mandatory Drug Testing' outlined different rules that could be applied in relation to the collection of urine samples during 'religious festivals which involve total fasting' but these did not apply in the present case since it was not a religious festival. The Adjudicator concluded that although there is nothing to stop individuals fasting on other days, they then bear the consequences of this. ${ }^{87}$

\footnotetext{
${ }^{86}$ [2011] EWHC 1108 (Admin).

${ }^{87}$ At para 6.
} 
At the High court, this adjudication was challenged as being, inter alia, contrary to Article 9 ECHR. Pelling QC, sitting as a High Court Judge, quashed the adjudication. He held that the circumstances required the Adjudicator to consider the applicability of Article 9, examining whether Article 9 was engaged, whether there was an interference with these rights and whether that interference had been justified under Article 9 (2). Simply considering applicability of the religious festival exception was 'a wrong approach' ${ }^{88}$

'The reasons given by the Adjudicator do not suggest that he considered the Article 9 point at all but rather simply considered the lawfulness issue by reference to the applicability of the religious festival exception. That was a wrong approach. The circumstances plainly required the applicability of Article 9 to be considered' ${ }^{89}$

As a result, the decision must be quashed since it could not be demonstrated that a reasonable Adjudicator correctly directing himself would have necessarily come to a similar conclusion as that reached by the Adjudicator in this case.

Unlike many of the cases, discussed above, the High Court in Bashir did not feel the need to erect any of the barriers in front of the claimant. Pelling QC held that Article 9 was engaged because there was 'no real doubt' that the claimant's fast was intimately linked to his religious belief. ${ }^{90}$ Moreover, Pelling QC rejected the defendant's submission that the relied on the fact that the fast was not obligatory but voluntary:

'Although the Defendant relies on the fact that the fast being undertaken by the Claimant was not obligatory but voluntary, I reject that as a relevant consideration for present purposes. There is nothing within Article 9 that requires there to be a perceived, much less an objectively demonstrable, obligation for the manifestation of religious belief to be protectable. Lord Nicholls does not suggest that to be so in Paragraph 32 of his Opinion in Williamson. Indeed, he says quite the opposite in paragraph 33. On the evidence before the Adjudicator the Claimant's fasting was a

\footnotetext{
${ }^{88}$ At para 16.

${ }^{89}$ Ibid.

${ }^{90}$ At para 20.
} 
manifestation that was motivated or inspired by a religion and was not unreasonable and thus satisfied the relevant threshold requirements for Article 9 to be engaged.' 91

This corrects the misinterpretation of Williamson in Playfoot (and also seems contrary to the spirit of Eweida). However, it also dismantles the distinction drawn in Arrowsmith between manifestations and motivations and seemingly introduces a new reasonableness test (which if applied objectively would be contrary to Lord Nicholl's insistence in Williamson that 'Freedom of religion protects the subjective belief of an individual'. ${ }^{92}$

Pelling QC also gave short shrift to the adjudicator's argument that relied upon Lord Bingham's rule in Begum on the basis that:

'none of the authorities that are considered by Lord Bingham in that paragraph concern the position of prisoners. Although it was argued on behalf of the Defendant that the Claimant should be treated as having voluntarily accepted the restrictions implicit in a prison environment by committing the offences for which he had been convicted, I am not convinced that is a correct analysis' ${ }^{93}$

He pointed out that 'The only European Court of Human Rights (ECtHR) authority cited by either party that concerned a prisoner was Jakobski $v$ Poland ${ }^{94}$. This may be the case but there are other clear examples of the specific situation rule being applied in the prison context, such as in $X v$ United Kingdom ${ }^{95}$. However, if the specific situation rule does not apply in a prison setting where the claimant has broken the social contract with society, it is

\footnotetext{
91 At para 21.

${ }^{92} R v$ Secretary of State for Education and Employment and others, ex parte Williamson [2005] UKHL 15, at para 22. . Indeed Pelling QC did not take a purely subjective approach. In reaching his conclusion that the fasting was a manifestation of his religion or belief, Pelling QC placed weight upon the fact that the claimant had been advised to embark on a three day fast by an Imam and that the Prison Imam had given evidence that 'personal fasting was a recognised tenet of Islam and there was an apparently objectively good reason for the Claimant wanting to undertake such a fast': as spiritual preparation for his impending appearance at the Court of Appeal (para 20). Pelling QC's reliance on the views of the Imam, his reference to the need for an 'objectively good reason' for the manifestation of religion and his assumption of competency to assert what is and what is not 'a recognised tenet of Islam' are all questionable. It seems that the High Court was seeking to determine the genuineness of Bashir's claim contrary to the principles laid out in Williamson. However, there seems to be some contradiction in the judgment since in paragraph 18 Pelling QC held that 'The Officer's evidence is of no value in determining the genuineness of the claimant's belief as to whether the fast could be broken'.

${ }^{93}$ Para 22.

${ }^{94}$ Application Number: 18429/06 (7 December 2011).

95 (1974) 1 D\& R 41
} 
arguable that it should not apply to other situations outside those regulated by a contract of employment. This seems to adopt a much narrower interpretation of the principle than we have seen in the cases above.

Further, Pelling QC also adopted a much more generous general approach to the question of interference:

'in my judgment the question of whether there has been interference becomes essentially a factual one. Having accepted that for the Claimant to embark upon and maintain a three day fast which he genuinely believed could not be broken was a manifestation of his religious beliefs, it necessarily follows that to require him to provide a sample of urine which he was not able to provide without breaking his fast was an interference with the Claimant's Article 9 rights. Thus, I conclude that the sole issue that arises in the circumstances of this case is ... whether the interference is prescribed by law, has one of the legitimate aims identified in Article 9(2) and is proportionate'. 96

This shifts the focus from the question of interference under Article 9(1) onto the question of justification under Article 9(2). Pelling QC concluded that this interference was not justified under Article 9(2) in that although the drug testing policy was 'prescribed by law' and fulfilled at least one of the legitimate aims laid out in the Article, it was not proportionate. ${ }^{97}$ There was no evidence before the Adjudicator concerning the cost or inconvenience of making appropriate adjustments in the particular circumstances that arose. ${ }^{98}$ As Pelling QC concluded: 'There was no evidence before the Adjudicator which enabled him to conclude (as apparently he did) that it was proportionate to require all Muslim prisoners engaged in personal fasting to break that fast as and when required to do so for the purposes of providing a [sample] regardless of the circumstances'. ${ }^{99}$

\footnotetext{
${ }^{96}$ At para 23.

97 At para 24

${ }^{98}$ At para 28.

${ }^{99}$ At para 29.
} 
Pelling QC stressed that his judgment was not intended to have any effect on the lawfulness of the drug testing policy and that the conclusions were 'case specific and fact sensitive'. ${ }^{100}$ However, although this case has not been cited, it seems to be representative of a changing interpretation of Article 9 in the lower courts.

This can be shown by the treatment of the specific situation rule in National Secular Society $v$ Bideford Town Council ${ }^{101}$. Although the Article 9 claim would have been unsuccessful (on the assumption that the saying of prayers was lawful), Ouselely $\mathbf{J}$ stated that there had been no voluntary submission in this case:

'I do not accept Mr Dingemans' argument that because Mr Bone had chosen to stand for election to a Council which had this practice, he had accepted the burden of its continuance until he could change it by democratic vote. ... This fails to recognise that becoming an elected representative is more than just a job for a politician; it is the fundamental right of the electorate to choose whom they wish to represent them in the body to which they have elected him. If it is an interference with the right not to hold religious views, or if it is an unnecessary or unjustifiable interference or act of discrimination, this cannot be treated as a case of voluntary submission., 102

This would suggest that there remains some limits to the specific situation rule can be applied. This tendency not to rely on the notion of contracting out can be further shown by recent litigation concerning the 'Occupy Movement' which formed a camp in St Paul's Cathedral Churchyard, The Mayor, Commonality and Citizens of London v Tammy Samede ${ }^{103}$. For current purposes, we are concerned only with the argument that allowing the camp to remain breached the Article 9 rights of St Paul's Cathedral. Although the Cathedral was not a party to the case, this was one of the reasons put forward in the argument that the interference with the protestor's Article 10 and 11 rights was not justified.

\footnotetext{
${ }^{100}$ At para 34; further, '[i]n any subsequent case where lawfulness is challenged on Article 9 grounds, each of the three questions I have identified above will have to be asked. The answers that will be arrived at will depend entirely upon the evidence before the Adjudicator before whom the issue is raised'.

${ }^{101}$ [2012] EWHC 175 (Admin).

102 Para 75.

${ }^{103}$ [2012] EWHC 34 (QB); [2012] EWCA Civ 160.
} 
In the High Court ${ }^{104}$ Lindblom $\mathrm{J}$ held that the City had undoubtedly established that there was a pressing social need to not to permit the camp to remain at the Cathedral and that this was in part because of the effect the occupation had on the Article 9 rights of the Cathedral:

'I am convinced that the effects of Occupy's protest camp in St Paul's Churchyard have been such as to interfere seriously with the rights, under Article 9 of the Convention, of those who desire to worship in the cathedral. ... During the camp's presence, and, in my view, largely if not totally as a result of its presence, there has been a drop of about two fifths in the numbers of those worshipping in the cathedral. About the same fraction has been lost in the number of visitors, an important source of funds for the upkeep of the building and for its ministry. .... Together, and without more, [this] would, in my view, justify the granting of relief. I have no hesitation in reaching that conclusion even though the Church is not itself a party in the City's claim and has not issued proceedings of its own.' 105

Like in Bashir, the specific situation rule was held not to apply:

'To say that those who are put off attending services in the cathedral can go and worship elsewhere, with more than 450 other churches in the diocese of London to choose from, misses the point. It is to misunderstand the nature of the right in Article 9, which is not that one is entitled to worship only where the activities of others make it comfortable or convenient to do so, or where one is made to go by others in the exercise of their own Convention rights, but where one chooses to worship in accordance with the law.' 106

In the Court of Appeal, ${ }^{107}$ the Master of the Rolls upheld the decision of the High Court, holding that there was "no chance that any of the criticisms raised by each of the defendants, or even all of those criticisms taken together, could persuade an appellate court that his decision was wrong'. ${ }^{108}$ In relation to the Article 9 point, the appellants contended that

\footnotetext{
${ }^{104}$ [2012] EWHC 34 (QB).

105 Para 162

${ }^{106}$ Para 162

107 [2012] EWCA Civ 160.

${ }^{108}$ Para 60.
} 
'the Judge ought not to have found ... that there was any interference with the rights of those who wished to worship at St Paul's Cathedral, given that (a) no worshipper gave evidence, and (b) the Occupy Movement stands for the same values as the Church of England'. 109

The Master of the Rolls held that neither of these arguments held sway because:

'As to (a), the Judge was plainly entitled to reach the conclusion that he arrived at. $\mathrm{He}$ had figures which showed a very significant reduction in worshippers at, and visitors to, the Cathedral since the Camp had arrived, and evidence of opinion from the Cathedral Registrar that the reduction was caused by the Camp. While there were some other possible explanations for the reduction, the Judge was, to put it at its lowest, entitled to reach the view that he did. As to point (b), it is true that some prominent members of the Church of England have expressed support for the Camp, but that is no answer to the Judge's concern about the interference by the Camp with the access of people who wish to worship in the Cathedral'. ${ }^{110}$

The cases of Bashir, Bideford and Samede therefore show a tendency not to rely on the notion of contracting out to dismiss Article 9 claims. Although the Article 9 arguments were not successful in all these cases, the religious rights dimension seems to be considered in a much more mature and nuanced way. This is true of recent cases which have relied upon the notion of contracting out but have done so in the context of the Article 9(2) question of justification rather than the Article 9(1) question of interference. The decision in National Secular Society v Bideford Town Council ${ }^{111}$ provides some evidence of this. Although, as we have seen, Ouselely $\mathbf{J}$ stated that there had been no voluntary submission, he nevertheless considered the notion of contracting out but did so in the context of Article 9 generally.

'Mr Bone is free to stay or leave during prayers. It is in accordance with the law. It is not discriminatory, or to the extent that it is, it is justified. I cannot see that his freedom of religion, thought or conscience is infringed by the degree of embarrassment he feels, which is no more than is inherent in the exercise by the others of their freedom to manifest their religious beliefs, and his freedom to stay

\footnotetext{
109 Para 34.

${ }^{110}$ Para 34.

111 [2012] EWHC 175 (Admin).
} 
without participating or to leave. It is their freedom which would be infringed were he right .'112

This conflation of interference and justification issues can also be found in two recent Court of Appeal decisions.

\section{Hotel Reservations}

The Court of Appeal decision in Bull \& Bull v Hall \& Preddy ${ }^{113}$ concerned discrimination on grounds of sexual orientation. The religious actors, the Bulls, were the defendants not the claimants. They were hotel owners who preferred to let double accommodation to heterosexual married couples only' and so turned away a homosexual couple who had entered into a civil partnership. Rafferty LJ held that this constituted direct discrimination on grounds of sexual orientation because a 'homosexual couple cannot comply with the restriction because each party is of the same sex and therefore cannot marry' meaning that 'the criterion at the heart of the restriction, that the couple should be married, is necessarily linked to the characteristic of an heterosexual orientation' and there was therefore less favourable treatment on grounds of sexual orientation. ${ }^{114}$

Moreover, Rafferty LJ held that this conclusion was compatible with Article 9. At first instance, Andrew Rutherford, giving the judgment of Bristol County Court held that the hotelier's Article 9 rights had been affected. ${ }^{115}$ However, this was justified under Article 9(2) because 'in so far as the regulations [prohibiting discrimination on grounds of sexual orientation] do affect this right they are ... a necessary and proportionate intervention by the state to protect the rights of others'. ${ }^{116}$ At the very least, it can be said that the treatment of Article 9 here is a little cursory. The suggestion once again that the legal requirement not to discriminate on grounds of sexual orientation will automatically justify religious discrimination claims. ${ }^{117}$ However, there seems to be a welcome step away from the Begum precedent in that at least it was accepted that the religious rights were interfered with.

\footnotetext{
112 Para 72.

113 [2012] EWCA Civ 83.

${ }^{114}$ Para 40.

${ }^{115}$ Bristol County Court Case No 9BC02095/6 (4 $4^{\text {th }}$ January 2011).

${ }^{116}$ [2012] EWCA Civ 83 at para 39.

${ }^{117}$ See also the cases of Ladele and Johns, discussed above.
} 
In the Court of Appeal Rafferty LJ also concluded that: "the extent to which under the Regulations the restriction imposed by the Appellants upon the Respondents constitutes direct discrimination, and to the extent to which the Regulations limit the manifestation of the Appellants' religious beliefs, the limitations are necessary in a democratic society for the protection of the rights and freedoms of others. ${ }^{118}$

However, in reaching this conclusion Rafferty LJ made reference to the Article 9 case law to reach the conclusion that:

'the article did not protect hoteliers who claimed that their "religious beliefs justified their refusal to provide double beds to homosexual couples" as "the provision of hotel rooms is legal and occurs nowhere other than in an hotel", and the hoteliers could "'manifest [their] beliefs in many ways outside the commercial sphere.",119

This would seem to be an application of the contracting out doctrine in the context of providing an answer to the question of justification under Article 9(2) (as opposed to its usual application in response to the question of interference under Article 9(1)). Whilst many objections concerning the contracting out doctrine continue to apply here, its application under Article 9(2) is preferable to its application under Article 9(1). When the rule is applied under Article 9(1) then the finding is that there has been no interference with Article 9 and so the claim is automatically dismissed. In contrast, where the rule is applied under Article 9(1) then the finding is part of the wider question of justification, allowing the merits of the case to be examined. This would therefore appear to be a step in the right direction.

\section{Conscientious Objection}

This approach was also followed in a 'classic' case of where the specific situation rule would be applied. The Court of Appeal in Michael Peter Lyons $v R^{120}$ applied the specific situation rule in respect of a Medical Assistant to the Navy who appealed his conviction for intentionally disobeying a lawful command, inter alia, on the basis that the order contravened his Article 9 rights as a conscientious objector. Toulson LJ held that current arrangements

\footnotetext{
${ }^{118}$ Para 51

${ }^{119}$ Para 48, quoting from Pichon and Sajous v France Application 49853/99 (2 October 2001) but substituting the facts of the instant case.

${ }^{120}$ [2011] EWCA Civ 2808.
} 
considering conscientious objection had been followed and that this was not in breach of Article 9:

'A person who voluntarily enters military service undertakes serious responsibilities potentially involving the lives and safety of others. If he seeks to be discharged from further service on the ground of conscientious objection, it is right that there should be a proper process for deciding whether his claim is well-founded. Until that has been established it is necessary and just that he should continue to be subject to the requirements of military service and military discipline. Otherwise he could immediately escape from the responsibilities which he had voluntarily accepted, regardless of the consequent risk to others and regardless of whether or not his claim was well founded.'121

This is largely uncontroversial. If there is such a rule as the specific situation rule, then it clearly applies on these facts. However, interestingly, the part of the judgment which examined the Article 9 claim considered Article 9 as a whole and did not distinguish between the questions of interference and justification. Again, in this case, the specific situation rule appears to be applied as part of the analysis of the Article 9(2) question of justification rather than the Article 9(1) question of interference:

'the fact that a person has volunteered for military service, and so voluntarily accepted the responsibilities which go with such service, may be highly material when considering the balance to be struck between the individual's conscience and the interest of public safety, the protection of public order and the protection of the rights of others, to which article 9.2 refers'. ${ }^{122}$

This is to be welcomed. It represents a move towards focusing more on the question of justification under Article 9(2) rather than dismissing claims under the question of interference under Article 9(1). Michael Peter Lyons is in line with my reading of the Strasbourg jurisprudence: this is a case where the specific situation rule can be considered. So, but to a lesser extent, is Bull \& Bull and Bideford. Moreover, it is pleasing to see a number of cases such as Bashir and Samede where the specific situation rule is not applied.

\footnotetext{
${ }^{121}$ Para 31

${ }^{122}$ Para 28.
} 
Again, on my reading of the Strasbourg jurisprudence that is correct. However, if the Begum precedent was applied then all of these cases would have been dismissed under the Article 9(1) question of interference.

In short, the judiciary appear to be becoming more comfortable with Article 9(1) and are more willing to consider that Article 9(1) may be engaged. The trend, however, is not all one way. This is shown by the Court of Appeal decision in President of the Methodist Conference $v$ Preston $^{123}$ the latest in a long line of cases concerning whether ministers of religion can be regarded as employees. ${ }^{124}$ In New Testament Church of God v Stewart ${ }^{125}$ the Church appealed against the finding of the Employment Tribunal that a minister of religion whose position as a pastor had been terminated was an employee arguing inter alia, that this decision infringed their Article 9 rights. The Court of Appeal dismissed the appeal but expressed some enthusiasm for the Article 9 claim. Pill LJ held that the law should not readily impose a legal relationship on members of a religious community which would be contrary to their religious beliefs while Arden LJ held that:

'A religious organisation may, as one of its beliefs, consider that ministers should not have contracts of employment or that the state should not interfere in the way they conduct their organisation. If the state interferes with that belief, there may be an interference with the group's article 9 right (though the interference will not constitute a violation of article 9 if the conditions in article $9(2)$ are satisfied) ${ }^{126}$

\section{In President of the Methodist Conference v Preston ${ }^{127}$, however, Maurice Kay LJ held that} Article 9 was not material to the ratio of Stewart. ${ }^{128}$ He held that the 'potential role of Article 9 in cases such as this' was 'far more modest ${ }^{\text {, }}$ ' and referred to:

\footnotetext{
${ }^{123}$ [2011] EWCA Civ 1581.

${ }^{124}$ See also J Duddington, 'God, Caesar and the Employment Rights of Ministers of Religion’ (2007) 159 Law and Justice 129-135; F Cranmer, 'Clergy Employment, Judicial Review and the Free Presbyterian Church of Scotland' (2010) 12(3) Ecclesiastical Law Journal 355-360; and J Rivers, The Law of Organized Religion(Oxford University Press, Oxford 2010) chapter 4.

125 [2007] EWCA Civ 1004.

${ }^{126}$ Para 61.

${ }^{127}$ [2011] EWCA Civ 1581.

${ }^{128}$ Para 30.

${ }^{129}$ Para 32. He cited Arden LJ and Lawrence Collins LH in Stewart to support this. However, although he claims that Arden LJ 'took a less expansive approach' than Pill LJ, he bases this on the general points outlined by Arden LJ in para 62 of his judgment about the limits of the position in para 61 whilst ignoring the enthusiasm found within para 61 .
} 
'the unattractiveness and moral poverty of the attempted invocation of Article 9 in this case'. ${ }^{130}$

\section{The Final Problem}

In sum, the pattern found in the most recent case law seems to be as follows:

(i) The most recent cases suggest that a more generous approach is beginning to be taken in respect to interference with Article 9. Bashir corrects Playfoot to confirm that non-obligatory manifestations may be protected by Article 9 and, together with Samede (and to some extent Bideford) show a growing reluctance to rely upon the notion of voluntary submission to dismiss claims.

(ii) The decisions in Lyons, Bull \& Bull and Bideford suggest that where contracting out is an issue, it will now be part of the consideration of Article 9 as a whole. These decisions, overall, suggest that the judiciary appear to be becoming more comfortable with Article 9(1) and are more willing to consider that Article 9(1) may be engaged. However, the cursory dismissal of the Article 9 claim in Preston provides an important exception to this trend.

In short, there are tentative signs that some of the criticisms previously made of the domestic Article 9 case law are now being rectified. This is an important qualifier to a recent report by the Equality and Human Rights Commission which has identified two concerns in relation to the domestic interpretation of Article 9:

"Courts are setting too high a threshold for establishing "interference" with the right to manifest a religion or belief, and are therefore not properly addressing whether limitations on Article 9 rights are justifiable.'

'Indirect discrimination provisions in domestic law covering protection for individual beliefs may not be consistent with Article 9'. ${ }^{131}$

\footnotetext{
${ }^{130}$ Para 34.

$131<$ http://www.equalityhumanrights.com/uploaded_files/humanrights/hrr_article_9.pdf >
} 
These concerns mirror those identified above. Moreover, just because there are some tentative signs that these concerns are beginning to be addressed, that does not mean that these concerns ought to be ignored. Indeed, the encouraging developments described above have all been lower court decisions. It remains to be seen what will happen in the next Supreme Court decision. Moreover, the cases currently pending appeal at Strasbourg are likely to have a significant effect on how Article 9 is interpreted.

This raises the question of how Article 9 should be interpreted. The short answer is increasingly by reference to the question of justification rather than the question of interference. However, that is not to say that the question of interference should always become a mere formality. The real issue is the scope of the specific situation rule: do we follow the tests as laid out by Lord Bingham in Begum and if we do how much emphasis do we place on each test. In other words, is it the specific situation rule or the contracting out doctrine?

Taking a step backwards, the objections to the specific situation rule / contracting out doctrine highlights the main difficulty with current interpretations of religious rights. It is based upon a 'binary' understanding of identity and authority. If a believer chooses to enter the public sphere then they are expected to leave their religiosity at the door of their workplace or school. There seems to be an acceptance that religious freedom is protected provided that the believer has a 'right to exit' from situations where they are not permitted to manifest their religion. This term is often used in the context of concerns about discriminatory practices within religious groups. It is argued that the role of the State is simply to ensure that people have the option to leave such groups. ${ }^{132}$ Reliance upon the 'right to exit' is flawed in that that context and in the context of a believer in a secular environment. As Phillips puts it, the 'right to exit' alone is insufficient because 'voice matters as well as exit. The right to leave has to be complemented by the right to stay'. ${ }^{133}$ As Shachar argues that this right to exit imposes 'the burden of solving conflict upon the individual' whilst

\footnotetext{
${ }^{132}$ For discussion and criticism, see e.g., the chapters by Reitman and Weinstock in A Eisenberg and SpinnerHalev (eds), Minorities within Minorities: Equality, Rights and Diversity (Cambridge University Press, 2005). Phillips denounces the 'right to exit' rationale as not attaching 'enough significance to cultural belonging': Phillips (A Phillips, Multiculturalism Without Culture (Princetown University Press, 2007) 133. She writes that it is based on a 'constructivist account of culture and universalist account of human nature' (ibid 135) ${ }^{133}$ Ibid 157.
} 
'relieving the state of any responsibility for the situation'. ${ }^{134}$ In short, it creates an impossible choice.

As the Canadian scholar Shachar has observed, this 'binary' understanding is fundamentally flawed because it is based on an oversimplified "either-or"- type understanding of legal authority which is not tailored to respect individuals' manifold identities'. ${ }^{135}$ Judges and tribunal chairs seem to be operating under the presumption that religion does not affect all aspects of a believer's life. Shachar therefore seeks to recognise 'the complex and multilayered nature of multicultural identity'. ${ }^{136}$ She asserts that we cannot 'remain blind to the web of complex and overlapping affiliations which exist between these competing entities'. ${ }^{137}$ This point was well made by the Archbishop of Canterbury's' lecture on religious law which relied heavily upon some aspects of Shachar's work. Rowan Williams asserted that: 'our social identities are not constituted by one exclusive set of relations or mode of belonging'. He said:

'There is a position - not at all unfamiliar in contemporary discussion - which says that to be a citizen is essentially and simply to be under the rule of the uniform law of a sovereign state, in such a way that any other relations, commitments or protocols of behaviour belong exclusively to the realm of the private and of individual choice. [This] is a very unsatisfactory account of political reality in modern societies; but it is also a problematic basis for thinking of the legal category of citizenship and the nature of human interdependence. ${ }^{138}$

\footnotetext{
${ }^{134}$ A Shachar, Multicultural Jurisdictions: Cultural Differences and Women's Rights (Cambridge, Cambridge University Press 2001) 41. As Levy points out, 'to have a culture whose exit is entirely costless ... is to have no culture at all': J T Levy, The Multiculturalism of Fear (Oxford University Press 2000) 112.

${ }^{135}$ A Shachar, Multicultural Jurisdictions: Cultural Differences and Women's Rights (Cambridge, Cambridge University Press 2001) 12. A similar point is made by Büchler who calls for the '(de-)construction of binary oppositions' in the context of determining the family law applicable to an individual on the basis of their nationality': A Büchler, Islamic Law in Europe? (Aldershot, Ashgate 2011) 131.

${ }^{136}$ A Shachar, Multicultural Jurisdictions: Cultural Differences and Women's Rights (Cambridge, Cambridge University Press 2001) 15.

137 Ibid 5. This point was developed by the Archbishop in his lecture which included a call for the recognition of 'multiple affiliations', by which he meant the recognition that people take 'membership in different but overlapping sets of social relationship': R Williams, 'Civil and Religious Law in England - A Religious Perspective' (2008) 10 Ecclesiastical Law Journal 262, 269.

${ }^{138}$ In the same lecture he later commented that: 'Societies that are in fact ethnically, culturally and religiously diverse are societies in which identity is formed, as we have noted by different modes and contexts of belonging, "multiple affiliation". The danger is in acting as if the authority that managed the abstract level of equal citizenship represented a sovereign order which then allowed other levels to exist. But if the reality of society is plural - as many political theorists have pointed out - this is a damagingly inadequate account of common life, in which certain kinds of affiliation are marginalised or privatised to the extent that what is
} 
Shachar argues that a "new approach to multicultural accommodation must break away from the prevailing yet misleading "either your culture or your rights" ultimatum that underpins existing solutions'. ${ }^{139}$ Shachar's solution lies in the acceptance of 'joint governance' which 'promises to foster ongoing interaction between different sources of authority, as a means of improving the situation of traditionally vulnerable insiders without forcing them to adhere to an either/or choice between their culture and their rights'. ${ }^{140}$

The recognition of the multi-faceted nature of identity as something which is constantly being re-negotiated and the notion that people may feel allegiance to more than one source of authority is, of course, by no means novel. However, these insights seem to have been lost in the domestic jurisprudence on Article 9 following Begum. The cases of $X v Y$ School, Playfoot and Eweida adopted a simplistic binary understanding of the religious claims. And, although recent lower court decisions suggest that certain aspects of this case law have been corrected, the problems identified by this paper and by the Equality and Human Right Commission have not gone away. It may well be that Strasbourg will provide some steer on these issues but only time will tell. It is crude and unhelpful to say that the juridification of religion has led to the persecution of religion; but it seems to be the case that the increase in language of religious rights has been met with signs of religious illiteracy on the part of some judges.

produced is a ghettoised pattern of social life, in which particular sorts of interest and of reasoning are tolerated as private matters but never granted legitimacy in public as part of a continuing debate about shared goods and priorities.'

${ }^{139}$ A Shachar, Multicultural Jurisdictions: Cultural Differences and Women's Rights (Cambridge, Cambridge University Press 2001) 5 .

${ }^{140}$ Ibid 88. 